\title{
Seasonal Variations of Phosphorus Species in the Overlying and Pore Waters of the Tuohe River, China
}

\author{
Qing Xu, ${ }^{1,2}$ Xiaoping Yu $\left(\mathbb{D},{ }^{1}\right.$ Yafei Guo $\mathbb{D}^{1},{ }^{1}$ Tianlong Deng $\left(\mathbb{D},{ }^{1}\right.$ Yu-Wei Chen, ${ }^{3}$ \\ and Nelson Belzile iD ${ }^{3}$ \\ ${ }^{1}$ Tianjin Key Laboratory of Brine Chemical Engineering and Resource Eco-utilization, \\ Tianjin University of Sciences and Technology, Tianjin 300457, China \\ ${ }^{2}$ School of Architecture and Civil Engineering, Chengdu University, Chengdu 610106, China \\ ${ }^{3}$ Department of Chemistry and Biochemistry, Laurentian University, Sudbury, Ontario P3E2C6, Canada \\ Correspondence should be addressed to Xiaoping Yu; yuxiaoping@tust.edu.cn and Tianlong Deng; tldeng@tust.edu.cn
}

Received 24 May 2019; Revised 14 August 2019; Accepted 2 September 2019; Published 30 October 2019

Academic Editor: Sedat Yurdakal

Copyright ( 2019 Qing Xu et al. This is an open access article distributed under the Creative Commons Attribution License, which permits unrestricted use, distribution, and reproduction in any medium, provided the original work is properly cited.

\begin{abstract}
Overlying sediment and pore waters were collected in summer and winter at upstream (Jintang) and downstream (Neijiang) sites of the Tuohe River, which is one of the five largest tributaries of the Yangtze River in China. Phosphorus species, including soluble reactive phosphorus (SRP), soluble unreactive phosphorus (SUP), and total dissolved phosphorus (TDP), and some diagenetic constituents including dissolved $\mathrm{Fe}(\mathrm{II}), \mathrm{Mn}(\mathrm{II})$, and sulfide in overlying and pore waters, were measured systematically. The seasonal variations and vertical distributions of phosphorus species in overlying and pore waters at both sampling sites were obtained to elucidate some aspects of the transport and transformations of phosphorus. Based on the profiles of pore and overlying waters as well as the TDN/TDP data during an algal bloom in 2007, it was clearly demonstrated that phosphorus was the main factor limiting the phytoplankton growth in the Tuohe River.
\end{abstract}

\section{Introduction}

Phosphorus is an essential nutrient for the growth of phytoplankton $[1,2]$, but its presence in excess, mostly due to anthropogenic activities, can cause eutrophication and lead to fast phytoplankton blooms in oceans, lakes, and rivers [3-5]. Since the recognition of the influence of phosphorus in water bodies [6], the scientific community has started to pay attention to the biogeochemistry of phosphorus in aquatic systems.

In natural waters, most of the soluble phosphorus is easily absorbed and utilized by aquatic organisms. In freshwater systems, phosphorus can be divided into total (TP), total dissolved (TDP), soluble reactive (SRP), soluble unreactive (SUP), and particulate phosphorus (PP) [7-9]. Sediments constitute the historical record of aquatic environments. The interaction between sediment and overlying waters via the sediment-water interface (SWI) could lead to the transport of phosphorus to the sediment as a storage site and also to the pore and overlying waters as a more available and more mobile source $[10,11]$. Therefore, the investigation of phosphorus species at the sediment-water interface is vital for the understanding of the aquatic environment and the nutrients involved in environmental biogeochemical processes.

The Tuohe River in China is one of the five largest tributaries of the Yangtze River [12]. In this paper, two sampling sites named Jintang and Neijiang, located upstream and downstream of the river, respectively, were investigated. Samples including the overlying and pore waters as well as the corresponding sediments were collected in summer and winter at the two sites. The concentrations of the different fractions of soluble phosphorus were determined, and the vertical distributions of phosphorus species in overlying and pore waters were thus obtained to shine some light on the transport and transformation of phosphorus in this river system.

\section{Materials and Methods}

2.1. Site Description. Sediment, overlying, and pore water samples were collected upstream at the Jintang site 
$\left(\mathrm{E} 104^{\circ} 31^{\prime} 19.0^{\prime \prime}, \mathrm{N} 30^{\circ} 43^{\prime} 44.2^{\prime \prime}\right)$ and downstream at the Neijiang site (E105 $01^{\prime} 48.9^{\prime \prime}, \mathrm{N} 29^{\circ} 35^{\prime} 49.8^{\prime \prime}$ ) (Figure 1) in August 2006 and January 2007.

2.2. Overlying and Pore Water Sampling. Pore water samples were collected using peepers based on the in situ steady state diffusion method $[13,14]$. Briefly, a volume of deoxygenated and demineralized water contained within a filtration membrane $(0.22 \mu \mathrm{m})$ is allowed to equilibrate with the overlying and pore waters after a Plexiglas support has been inserted in the sediments. After a 14-day in situ equilibration period, the peepers were retrieved from the sediment by a diver and sampled immediately onsite. In each corresponding depth, a $1 \mathrm{~mL}$ subsample was collected into a $5.0 \mathrm{~mL}$ precleaned Teflon container to react and fix dissolved sulfide for further analysis. A $1.0-2.0 \mathrm{~mL}$ subsample was used to measure the $\mathrm{pH}$, and the remaining volume of pore water was acidified to $\mathrm{pH}<2$ with ultrapure hydrochloric acid and stored at $4^{\circ} \mathrm{C}$ in a precleaned Teflon container for further determination of dissolved $\mathrm{Fe}$ [Fe(II)] and $\mathrm{Mn}$ $[\mathrm{Mn}(\mathrm{II})]$.

Limpid and not muddy overlying water was collected immediately in a $250 \mathrm{~mL}$ precleaned polyethylene container. Sediment cores were collected by a diver using a PVC corer at the same sites where pore water was collected. The sediments in the corer were sliced at each $1 \mathrm{~cm}$ depth and were placed in precleaned polyethylene containers using the method of coning and quartering. The results on the partitioning of phosphorus in solid sediments were reported previously [15]. All overlying and pore waters and sediment samples were stored in a glove-box bag filled with nitrogen gas to prevent oxidation and transported to the laboratory and kept frozen at $-80^{\circ} \mathrm{C}$ until analysis. Pore waters used for the analysis of phosphorus species were obtained by refrigerated centrifugation (speed of centrifugation $6000 \mathrm{rpm}$ ) of the sediment samples.

2.3. Analysis of Overlying and Pore Waters. Dissolved oxygen (DO), oxidation-reduction potential (ORP), and conductivity in the overlying waters were obtained using the in situ YSI probe at each $0.5 \mathrm{~m}$ depth in the central part of the river at the two sites of Jintang and Neijiang. The phosphorus species in both overlying and pore waters were identified and classified as soluble reactive (SRP), soluble unreactive (SUP), and total dissolved phosphorus (TDP) as described by Effler et al. [16]. SRP was analyzed using the phosphor-molybdenum blue spectrophotometric method [17] according to the Chinese National Standards (GB 17378.4-2007). TDP in water was determined following a potassium persulfate digestion under $1.1 \mathrm{~kg} / \mathrm{cm}^{2}$ pressure at $120^{\circ} \mathrm{C}$ for $30 \mathrm{~min}$ to completely transform all dissolved phosphorus into SRP and then determined as TDP. The SUP content was obtained by the difference between TDP and SRP. The detection limit for the determination of SRP or TDP was $0.2 \mu \mathrm{g} / \mathrm{L}$. The concentrations of $\mathrm{Fe}$ (II) and $\mathrm{Mn}$ (II) were determined using a flame/graphite atomic absorption spectrometer (Hitachi 180-80, Japan) [18]. The detection limits for $\mathrm{Fe}(\mathrm{II})$ and $\mathrm{Mn}(\mathrm{II})$ were $0.03 \mathrm{mg} / \mathrm{L}$ and $0.02 \mathrm{mg} / \mathrm{L}$, respectively. The

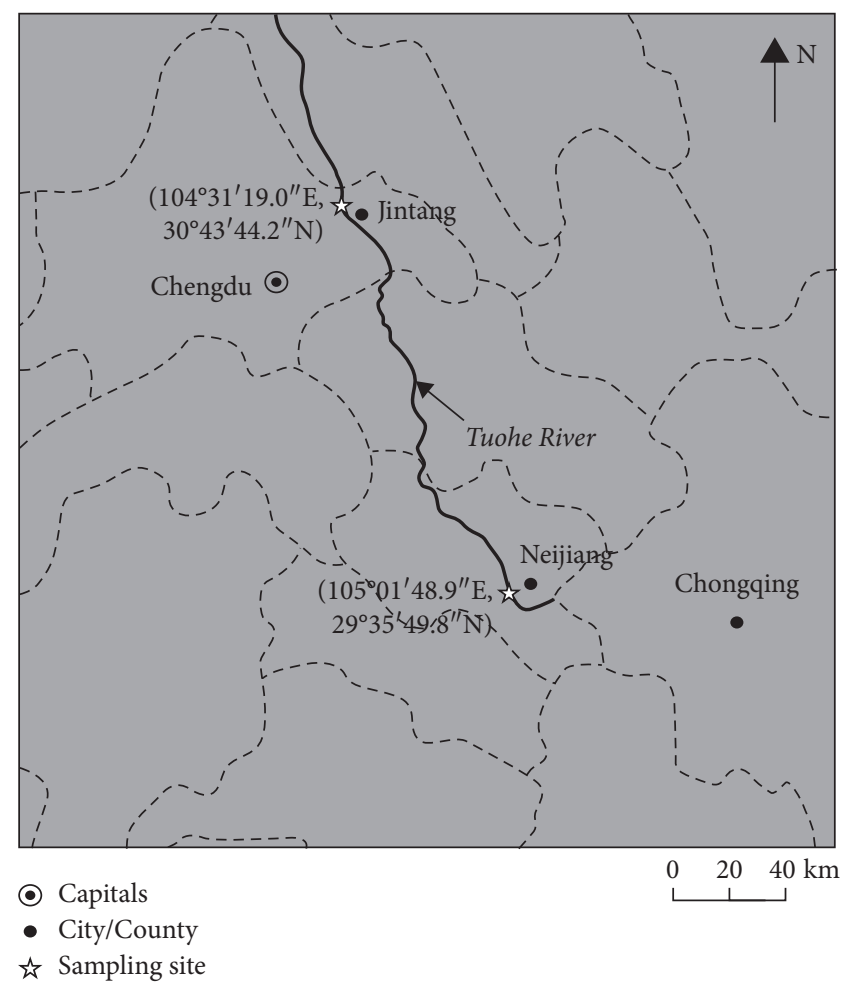

FIgURE 1: Sampling sites at Jintang (upstream) and Neijiang (downstream) on the Tuohe River.

concentrations of $\mathrm{S}^{2-}$ in overlying water and pore waters were determined by the aminodimethyl-phenyllammonium spectrophotometry [19], and the detection limit was $0.02 \mathrm{mg} / \mathrm{L}$.

A dilution plate colony counting method was used to enumerate phosphobacteria in triplicate. Phosphobacteria are aerobic bacteria that can enhance the degradation of SUP and the solubilization of phosphorus in the upper sediment pore waters. The plate count medium (NBRIP) was composed of $10 \mathrm{~g}$ of glucose, $5 \mathrm{~g}$ of $\mathrm{MgCl}_{2}, 0.1 \mathrm{~g}\left(\mathrm{NH}_{4}\right)_{2} \mathrm{SO}_{4}$, $0.25 \mathrm{~g}$ of $\mathrm{MgSO}_{4} \cdot 7 \mathrm{H}_{2} \mathrm{O}, 0.2 \mathrm{~g}$ of $\mathrm{KCl}, 25 \mathrm{~g}$ of $\mathrm{Ca}_{3}\left(\mathrm{PO}_{4}\right)_{2}$, and $25 \mathrm{~g}$ of agar completed to $1000 \mathrm{~mL}$ with deionized water. It was sterilized at $112^{\circ} \mathrm{C}$ for $30 \mathrm{~min}$ [20]. $10 \mathrm{~g}$ of sediment sample and $250 \mathrm{~mL}$ of sterile water were added into an Erlenmeyer flask with embedded glass beads. The flask was shaken for $30 \mathrm{~min}$ at $170 \mathrm{rpm}$. A tenfold dilution series was made to form $10^{-4}, 10^{-5}, 10^{-6}$, and $10^{-7}$ suspensions. Portions of $0.1 \mathrm{~mL}$ were spread on PVK solid plate medium in triplicate. Colonies were counted after culturing at $28^{\circ} \mathrm{C}$ for 3 to 5 days.

\section{Results and Discussion}

3.1. Profiles of DO, $p H$, Conductivity, and ORP in Overlying Waters. The physicochemical parameters of a river are used to determine the water quality. For the sediments, important changes of these parameters in the overlying waters will greatly affect the migration and transformations of elements. Therefore, the determination of physicochemical parameters in the overlying waters is fundamental to understand the 
basic properties and characteristics of the river. The results of physicochemical parameters of the overlying waters in two seasons at the two sampling sites are shown in Tables 1 and 2, respectively (no winter data are available for Jintang). Water temperature was the highest in summer, with higher temperatures of the overlying waters being measured at the Neijiang site. In summer, DO ranged slightly from 6.06 to $6.43 \mathrm{mg} / \mathrm{L}$ at Jintang and from 5.76 to $6.07 \mathrm{mg} / \mathrm{L}$ in Neijiang, whereas DO fluctuated from 8.06 to $8.58 \mathrm{mg} / \mathrm{L}$ at Neijiang in winter. The $\mathrm{pH}$ in the overlying waters at Jintang was 7.87; at Neijiang, it averaged to 8.10 in summer and 7.96 in winter. Overall, the vertical distribution of conductivity, temperature, and $\mathrm{pH}$ showed very little change with depth. However, DO and ORP showed larger spatial and seasonal variations as these parameters are more sensitive to environmental change.

\subsection{Distributions of $p H$ and Dissolved Sulfide in Pore Waters} and at the SWI at the Two Sites. The distributions of $\mathrm{pH}$ and dissolved sulfide in pore waters at Jintang and Neijiang are shown in Figure 2. Pore water at Jintang showed alkaline values both in summer and winter, and they were higher than at Neijiang where the pore water $\mathrm{pH}$ values were generally near neutral. Generally, the pore water $\mathrm{pH}$ at the two sampling sites decreased gradually with depth.

The average pore water concentration of dissolved sulfide (mainly $\mathrm{HS}^{-}$at this $\mathrm{pH}$ ) at Jintang was $0.45 \mathrm{mg} / \mathrm{L}$, whereas it was $0.85 \mathrm{mg} / \mathrm{L}$ at the Neijiang site. Dissolved sulfide in the overlying waters of Jintang in summer was lower than the average concentration as expected from DO concentrations over the sediment. Two small peaks were observed: at $-14 \mathrm{~cm}$ and $-26 \mathrm{~cm}$. The average concentration of dissolved sulfide in the pore water at the Neijiang site in summer was higher than that at Jintang, and two peaks appeared at $-4 \mathrm{~cm}$ with $4.72 \mathrm{mg} / \mathrm{L}$ and $-12 \mathrm{~cm}$ with $1.90 \mathrm{mg} /$ $\mathrm{L}$, indicating sulfate reducing conditions at such depths as a consequence of the mineralization of organic matter.

At the Jintang site, the concentration of dissolved sulfide was lower in winter than in summer. This is likely due to higher DO in the overlying waters in winter and lessened bacterial activity in the sediment at lower temperature. Sulfate cannot be easily reduced to $\mathrm{HS}^{-} / \mathrm{S}^{2-}$ at the SWI when higher concentrations of DO are present in overlying waters.

3.3. Distributions of Phosphorus Species in Overlying and Pore Waters. At the Jintang site, the vertical distributions of $\mathrm{Fe}(\mathrm{II})$ and $\mathrm{Mn}(\mathrm{II})$ were similar (Figures 3(a) and 3(b)), and the correlation between those two parameters was 0.94 in summer. A first concentration peak appeared at $-2 \mathrm{~cm}$ $(10.82 \mathrm{mg} / \mathrm{L} \mathrm{Fe}(\mathrm{II})$ and $5.59 \mathrm{mg} / \mathrm{L} \mathrm{Mn}(\mathrm{II}))$, and then values decreased to a minimum at $-8 \mathrm{~cm}(2.3 \mathrm{mg} / \mathrm{L} \mathrm{Fe}(\mathrm{II})$ and $1.02 \mathrm{mg} / \mathrm{L} \mathrm{Mn}(\mathrm{II}))$ and increased again at $-10 \mathrm{~cm}$, where dissolved $\mathrm{Fe}$ and $\mathrm{Mn}$ reached maximum values of $15.25 \mathrm{mg} / \mathrm{L}$ for $\mathrm{Fe}(\mathrm{II})$ and $4.85 \mathrm{mg} / \mathrm{L}$ for $\mathrm{Mn}$ (II). This indicates the occurrence of relatively reducing environments at about $-2 \mathrm{~cm}$ and $-10 \mathrm{~cm}$, where $\mathrm{Fe}$ and $\mathrm{Mn}$ oxides are being used as electron acceptors for the mineralization of organic matter. This is also consistent with the distribution of $\mathrm{HS}^{-} / \mathrm{S}^{2-}$ in pore water in summer at the Jintang site. At this site, the average concentration of SRP in pore water was $0.081 \mathrm{mg} / \mathrm{L}$, or $32.9 \%$ of TDP, and it generally decreased with increasing depth (Figure 3(c)). SUP was the most important fraction of TDP, averaging $0.17 \mathrm{mg} / \mathrm{L}$ or $67.5 \%$ of TDP and following approximately the same trend as TDP with depth. If we assume that SRP represents orthophosphates, it can be expected that the high concentrations of dissolved $\mathrm{Fe}$ and $\mathrm{Mn}$ (in the millimolar range) and those of phosphates (in the $\mu$ molar range) at the same depths will likely exceed the solubility product of a compound such as vivianite, $\mathrm{Fe}_{3}\left(\mathrm{PO}_{4}\right)_{2}$ or reddingite, and $\mathrm{Mn}_{3}\left(\mathrm{PO}_{4}\right)_{2}$ and therefore limit the solubility of SRP.

There are other possible factors that could explain the observed distribution characteristics of SRP. First, SRP in overlying waters was slightly higher than in pore water in summer, and the upward diffusion of phosphorus in the overlying waters led to higher SRP concentrations in upper porewaters. Second, with the increase of depth, the gradual onset of more reducing conditions steered the production of SRP and possibly SUP following the mineralization of organic matter, as most reactions using the various oxidants normally encountered in sediments such as Fe/Mn oxides, nitrates, or sulfates lead to the release of SRP [21]. In deeper sediments, orthophosphates can be reabsorbed onto the solid phase or (co-) precipitated as proposed above with $\mathrm{Fe}$, $\mathrm{Mn}$, or Ca (hydroxyapatite). Third, the vertical distribution of phosphobacteria at the Jintang site in summer as shown in Figure 3(d) was similar to the distribution of SRP. It also explains the relatively high proportion of SUP in deeper pore waters.

The depth distributions of dissolved Fe and $\mathrm{Mn}$ at the Jintang site in winter are shown in Figures 3(e) and 3(f), respectively. Below $-10 \mathrm{~cm}$, the distributions of these two elements were similar. A sharp peak appeared at $-11 \mathrm{~cm}$ $(6.43 \mathrm{mg} / \mathrm{L} \mathrm{Fe}(\mathrm{II})$ and $2.34 \mathrm{mg} / \mathrm{L} \mathrm{Mn}(\mathrm{II}))$ at a lower depth compared to the summer likely due to relatively higher DO concentration in winter. The concentrations of SRP, SUP, and TDP (Figure 3(g)) averaged $0.32(0.024-0.85), 0.073$ (0.011-0.24), and $0.39(0.044-1.09) \mathrm{mg} / \mathrm{L}$, respectively. This indicates that an average of $81.2 \%$ of TDP existed as SRP in pore waters in winter, and the vertical distributions of SRP and TDP were very similar (correlation 0.98). Figure 3(h) also shows the vertical distribution of phosphobacteria in winter. The distributions of SRP and SUP are clearly correlated with that of phosphobacteria. In April of 2007, there was a large-scale outbreak of water hyacinth at the Jintang site, shortly after the winter sampling. The concentrations of SRP and TDP in winter were much higher than those measured in summer, with average concentrations of SRP and TDP of 1.02 and $1.18 \mathrm{mg} / \mathrm{L}$, respectively. High values in overlying waters suggest diffusion from the overlying waters to the sediments. By comparing the contents of phosphorus species in the overlying waters of Jintang in winter and summer, we found that the overlying waters contained high concentrations of nutrients-phosphorus before the water hyacinth outbreak. Furthermore, because of the storage dam of the Kowloon Power Station in the Jintang section, the river in this section slowed down during winter. Because of 
TABLE 1: Results on the physicochemical parameters of overlying water of Jintang in summer, Tuohe River.

\begin{tabular}{|c|c|c|c|c|c|}
\hline \multirow{2}{*}{ Depth $(\mathrm{m})$} & \multicolumn{5}{|c|}{ Jintang (summer) } \\
\hline & $\mathrm{T}\left({ }^{\circ} \mathrm{C}\right)$ & $\mathrm{DO}(\mathrm{mg} / \mathrm{L})$ & $\mathrm{pH}$ & $\mathrm{L}(\mathrm{S} / \mathrm{m})$ & ORP $(\mathrm{mV})$ \\
\hline 0 & 21.22 & 6.22 & 7.89 & 0.612 & 66.8 \\
\hline-0.5 & 21.17 & 6.43 & 7.89 & 0.612 & 84.4 \\
\hline-1 & 21.04 & 6.35 & 7.87 & 0.610 & 81.4 \\
\hline-1.5 & 21.00 & 6.27 & 7.87 & 0.610 & 81.5 \\
\hline-2 & 21.00 & 6.28 & 7.87 & 0.610 & 79.2 \\
\hline-2.5 & 20.99 & 6.23 & 7.86 & 0.610 & 81.1 \\
\hline-3 & 20.98 & 6.23 & 7.86 & 0.609 & 78.6 \\
\hline-3.5 & 20.94 & 6.16 & 7.87 & 0.609 & 66.7 \\
\hline-4 & 20.92 & 6.06 & 7.87 & 0.609 & 65.7 \\
\hline
\end{tabular}

TABle 2: Results on the physicochemical parameters of overlying water of Neijiang in summer and winter, Tuohe River.

\begin{tabular}{|c|c|c|c|c|c|c|c|c|c|c|}
\hline \multirow{2}{*}{ Depth (m) } & \multicolumn{5}{|c|}{ Neijiang (summer) } & \multicolumn{5}{|c|}{ Neijiang (winter) } \\
\hline & $\mathrm{T}\left({ }^{\circ} \mathrm{C}\right)$ & $\mathrm{DO}(\mathrm{mg} / \mathrm{L})$ & $\mathrm{pH}$ & $\mathrm{L}(\mathrm{S} / \mathrm{m})$ & ORP $(\mathrm{mV})$ & $\mathrm{T}\left({ }^{\circ} \mathrm{C}\right)$ & $\mathrm{DO}(\mathrm{mg} / \mathrm{L})$ & $\mathrm{pH}$ & $\mathrm{L}(\mathrm{S} / \mathrm{m})$ & ORP $(\mathrm{mV})$ \\
\hline-0.5 & 29.76 & 5.96 & 8.10 & 0.743 & 102.6 & 8.85 & 8.06 & 7.96 & 0.465 & 47.6 \\
\hline-1 & 29.60 & 6.06 & 8.10 & 0.740 & 87.0 & 8.85 & 8.54 & 7.96 & 0.465 & 47.5 \\
\hline-1.5 & 29.59 & 6.07 & 8.10 & 0.740 & 84.9 & 8.85 & 8.58 & 7.95 & 0.465 & 51.3 \\
\hline-2 & 29.57 & 6.02 & 8.10 & 0.739 & 81.0 & 8.85 & 8.57 & 7.95 & 0.465 & 51.3 \\
\hline-2.5 & 29.58 & 6.02 & 8.09 & 0.740 & 78.7 & 8.85 & 8.49 & 7.89 & 0.465 & 7.3 \\
\hline-3 & 29.58 & 5.76 & 8.10 & 0.740 & 73.6 & 8.85 & 8.36 & 7.90 & 0.465 & 7.1 \\
\hline-3.5 & 29.58 & 5.87 & 8.09 & 0.739 & 69.8 & 8.85 & 8.32 & 7.89 & 0.465 & 5.7 \\
\hline-4 & 29.57 & 5.80 & 8.09 & 0.739 & 67.8 & 8.85 & 8.23 & 7.89 & 0.465 & 5.0 \\
\hline
\end{tabular}

the poor mobility of river water, the phosphorus in overlying waters has enough time to interact with the sediment system via the SWI. Due to the concentration gradient of phosphorus, a dynamic balance should be achieved between the phosphorus in the overlying and pore waters phosphorus, causing phosphorus in the overlying waters to diffuse into the pore waters.

The distribution of dissolved Fe/Mn and phosphorus species in overlying and pore waters at the Neijiang site in summer is shown in Figures 4(a) and 4(c). The vertical distributions of dissolved $\mathrm{Fe}$ and $\mathrm{Mn}$ at this downstream site were also similar to a correlation of 0.82 . A large peak of $\mathrm{Fe}(\mathrm{II})$ at $-5 \mathrm{~cm}(60.8 \mathrm{mg} / \mathrm{L}), \mathrm{Mn}(\mathrm{II})$ at $-7 \mathrm{~cm}(15 \mathrm{mg} / \mathrm{L})$, and the large concentration of $\mathrm{HS}^{-} / \mathrm{S}^{2-}$ (Figure 2) also at $-5 \mathrm{~cm}$ all indicate the existence of reducing conditions close to the SWI at this site in summer. Concentrations of the three dissolved components gradually decreased with increasing depth. The fluctuations in the concentrations of SRP (0.041-0.43), SUP (0.001-0.29), and TDP (0.13-0.67) $\mathrm{mg} / \mathrm{L}$ showed no specific trends, which might be related to the nature of the site characterized by sandy sediments. The composition of sediments is very likely an important factor affecting the vertical distribution of phosphorus in pore waters at the Neijiang site in summer.

Figures 4(d)-4(f) shows the distribution of phosphorus species in overlying and pore waters in Neijiang in winter. No obvious correlation was found between dissolved $\mathrm{Fe}$ and $\mathrm{Mn}$, and the few peaks of $\mathrm{Fe}$ (II) showed much lower concentrations than in summer at this site. The concentrations of SRP, SUP, and TDP were also fluctuated at this site where $56.1 \%$ of TDP in pore waters existed as SUP. The peaks of the various forms of phosphorus appeared almost at the same depth as $\mathrm{Fe}(\mathrm{II})$, indicating that the dominant factors reflecting the vertical distribution of phosphorus in winter at the Neijiang are related to the mineralization of organic matter and the phosphorus release from the sediment. As mentioned before, sand is an important component of the sediments in Neijiang where dissolved form of phosphorus can be adsorbed and desorbed as changes occur in water flow, biological stirring, etc. The composition, physicochemical properties, and surface characteristics of sediment particles are complex. Phosphorus adsorption can occur in two stages, the fast process of physical adsorption and a slow stage of chemical adsorption. Phosphorus adsorbed by physical adsorption cannot be strongly retained by the sediment particles and finally released as a result of flow shear stress [22]. The composition of the sediments in Neijiang may thus also reflect the distribution of SRP.

3.4. Seasonal Variation of Phosphorus Species in Overlying and Pore Waters at the Two Sites. In the overlying waters, the total dissolved phosphorus mainly exists in the form of SRP at the two sampling sites, both in summer and winter. Because of the relatively high DO levels in the overlying waters, the decomposing ability of bacteria for SUP is favoured. At the SWI, TDP mainly exists in the form of SUP except at Jintang in winter. This indicates that the SWI plays an important role in the diffusion of SRP under specific conditions.

In pore waters, SRP was mainly in the form of TDP at the Jintang site in winter, while it was SUP in summer. The situation at the Neijiang site was the opposite illustrating that the distributions of phosphorus species are influenced 


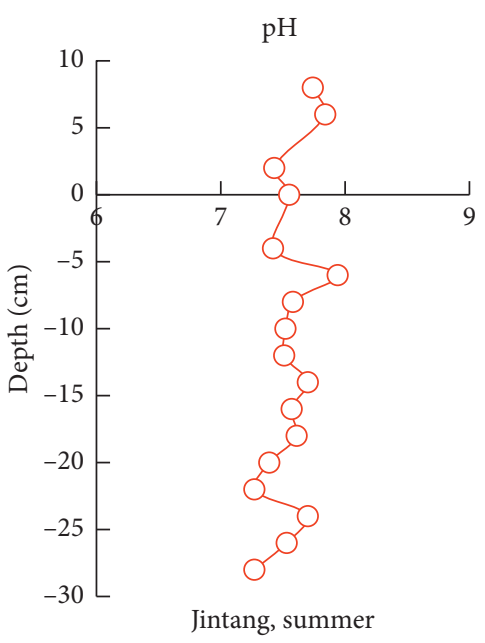

(a)

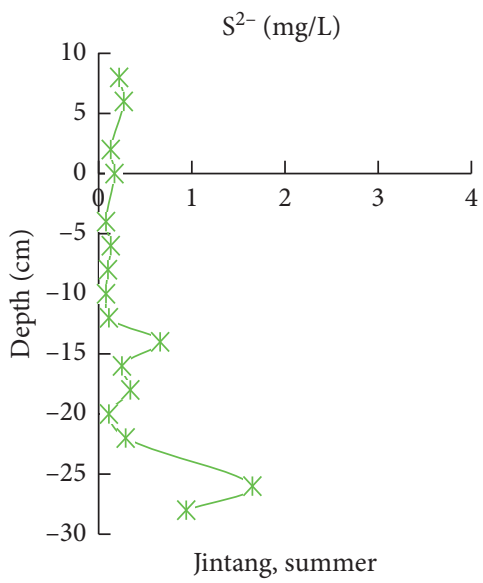

(d)

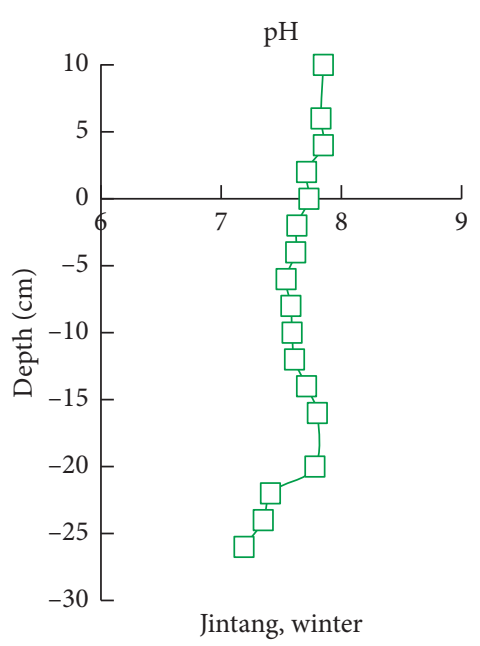

(b)

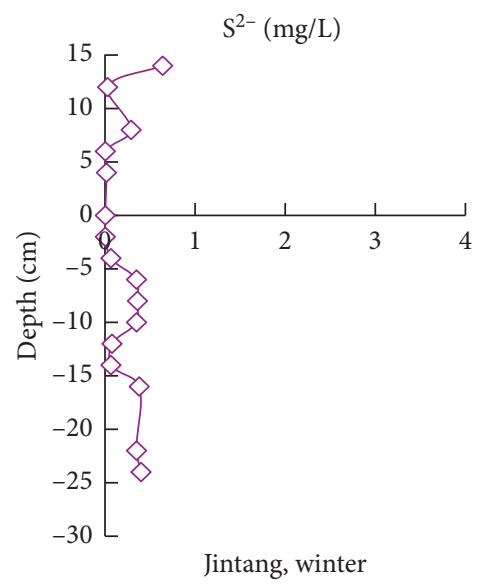

(e)

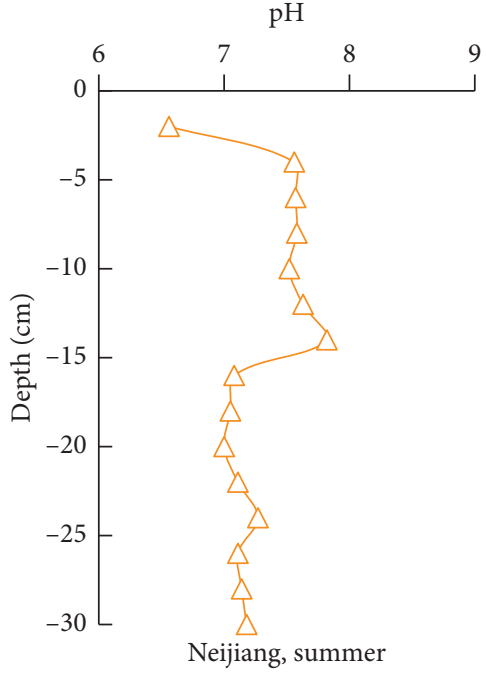

(c)

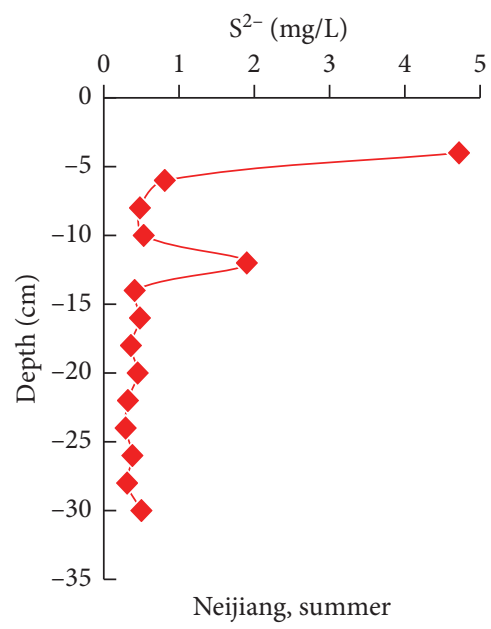

(f)

Figure 2: Profiles of $\mathrm{pH}$ and dissolved sulfide in pore waters at the two sampling sites, Tuohe River.



(a)

)
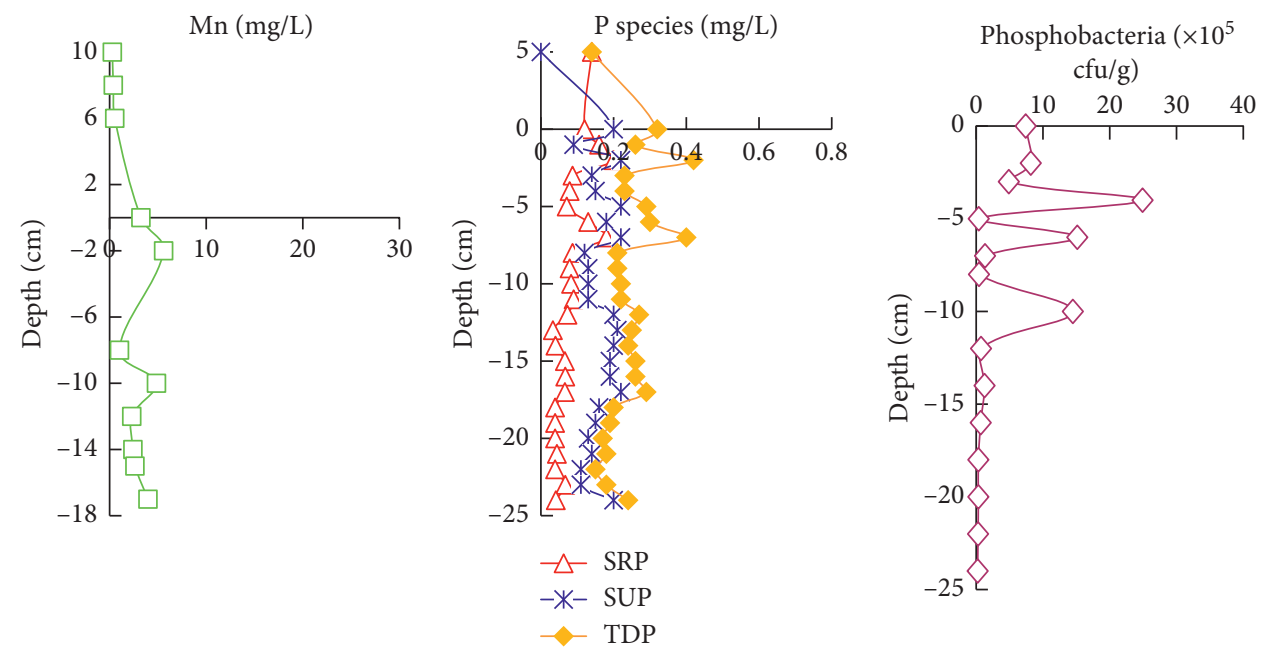

(b)

(c) (d)

Figure 3: Continued. 


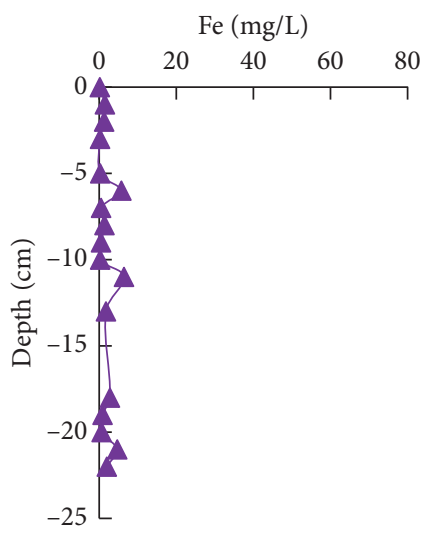

(e)

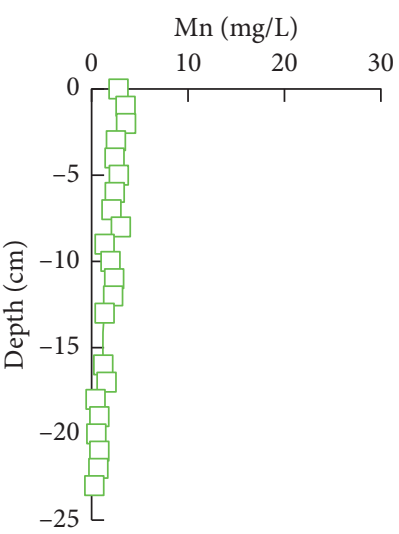

(f)

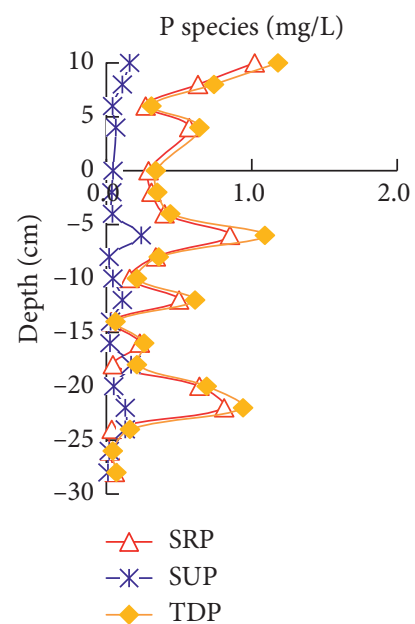

(g)

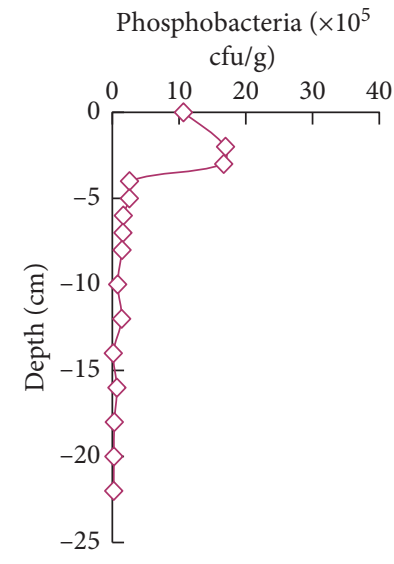

(h)

Figure 3: Vertical distributions of dissolved Fe (a), dissolved Mn (b), phosphorus species (c), and phosphobacteria (d) in pore waters at the Jintang site in summer, as well as dissolved Fe (e), dissolved Mn (f), phosphorus species (g), and phosphobacteria (h) in pore waters at the Jintang site in winter.

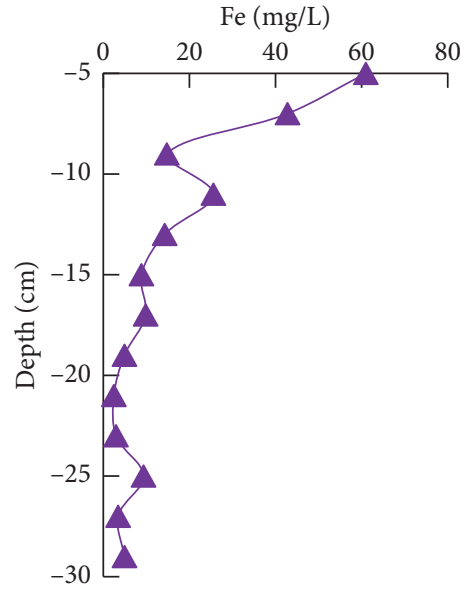

(a)

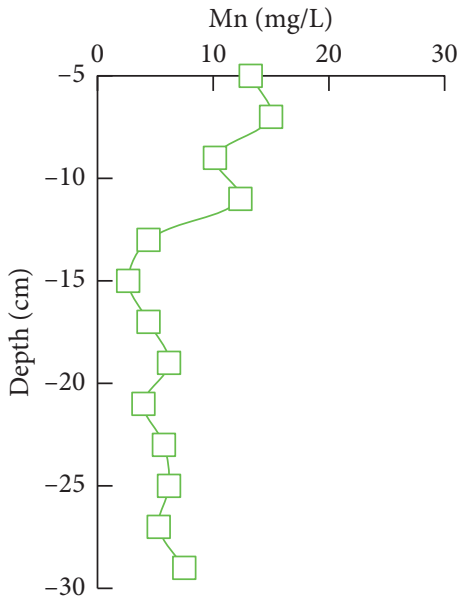

(b)

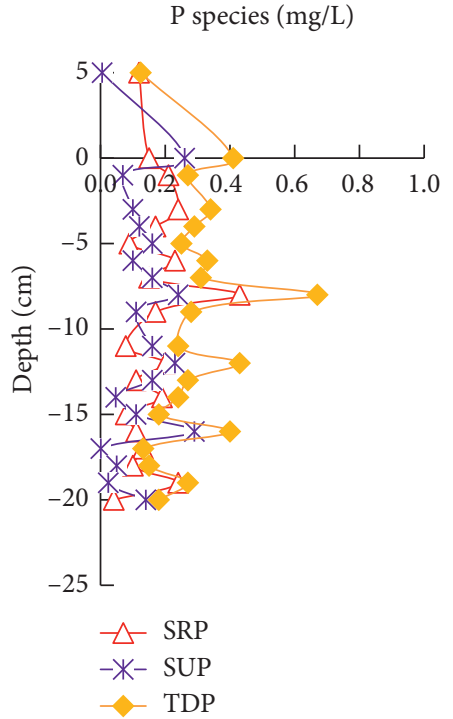

(c)

Figure 4: Continued. 


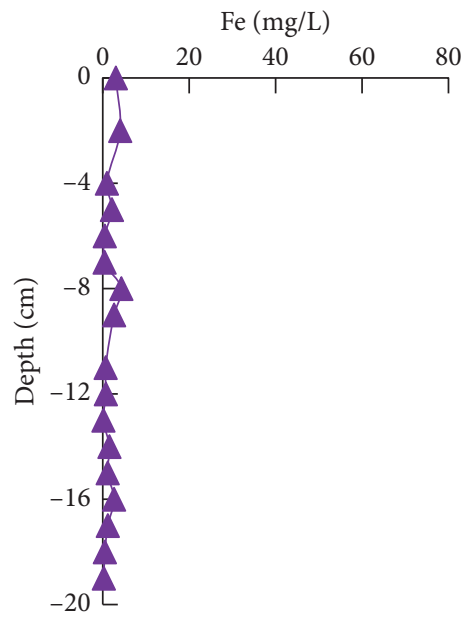

(d)

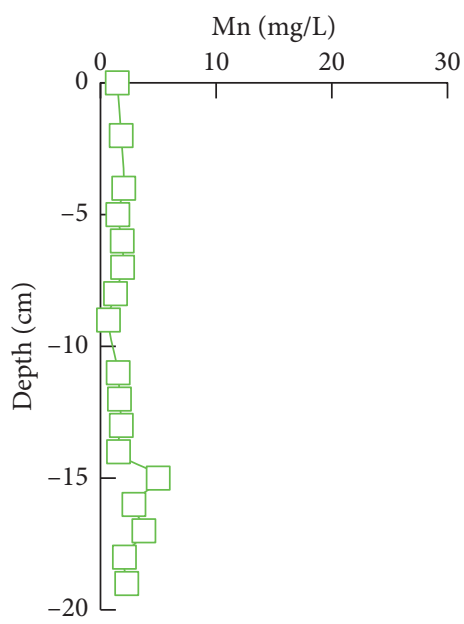

(e)
$\mathrm{P}$ species $(\mathrm{mg} / \mathrm{L})$

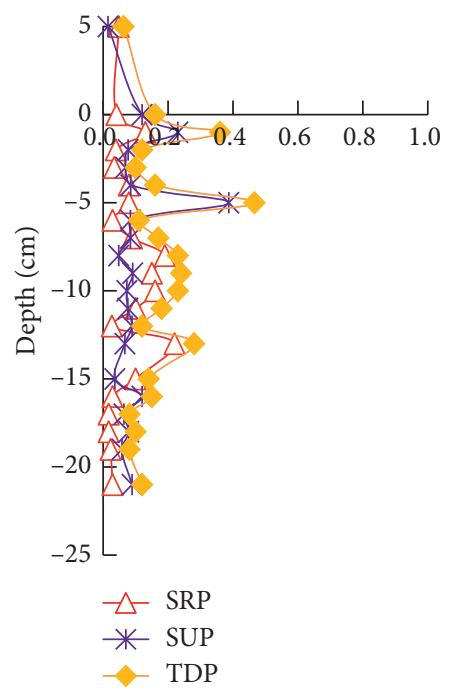

(f)

FIgURE 4: Vertical distributions of dissolved Fe (a), dissolved Mn (b), and phosphorus species (c) in pore waters at the Neijiang site in summer, as well as dissolved Fe (d), dissolved Mn (e), and phosphorus species (f) in pore waters at the Neijiang site in winter.

by many factors, and these factors are not independent of each other. Without taking the exogenous phosphorus pollution at the Jintang site in winter into account, the concentrations of all phosphorus species in summer were higher than those in winter. The same was true for $\mathrm{HS}^{-} / \mathrm{S}^{2-}$ in pore water (Figure 2) and also for dissolved Fe (Figure 3), indicating that the sedimentary milieu of pore waters was a reducing environment, conducive to release of $\mathrm{Fe} / \mathrm{Al}$ bounded phosphorus. Although DO levels in winter were higher than in summer, the microbial activity was relatively low in winter due to lower temperatures, so that the ability of decomposition of SUP by phosphobacteria was weak. In summer, the ability of aquatic plant reproduction is strong, and these may supply DO to the water by photosynthesis. When the aquatic plants die, the residues in summer are more abundant than in winter. Moreover, because of the stronger decomposition ability of SUP by phosphobacteria at higher temperatures, the concentrations of phosphorus species were higher in summer than in winter.

\subsection{Seasonal Variations of TDN/TDP in Overlying and Pore} Waters at the Two Sites. A typical alga should have an atomic composition of $\left(\mathrm{CH}_{2} \mathrm{O}\right)_{106}\left(\mathrm{NH}_{3}\right)_{16}\left(\mathrm{H}_{3} \mathrm{PO}_{4}\right)$, with a nitrogen/ phosphorus molar ratio of $16: 1$, which by weight is $7.2: 1$. The optimum ratio of nitrogen/phosphorus for the growth of water hyacinth is also $7: 1$ [23] which is basically the same as the molecular formula of typical alga. The vertical distributions of the ratio of total dissolved nitrogen (TDN) to TDP in overlying water and pore waters at Jintang (Figures 5(a) and 5(b)) and Neijiang (Figures 5(c) and 5(d)) calculated on the basis of the TDN data using the same samples for the two sampling sites in summer and winter determined by $\mathrm{Wu}$ [24] and Zhang [25] are shown in Figure 5. The TDN/TDP ratio in Jintang in summer was in the range of 40-273 in pore waters, whereas in winter, it was in the range of 5-221. At Neijiang, the TDN/TDP ratio in summer and winter was in the range of 12-562 and 45-483, respectively. In overlying water in Jintang and Neijiang in winter, the TDN/TDP was 6.61 and 53.49 , respectively. The ratio of TDN/TDP in the overlying water of Jintang in winter (6.61) was suitable for the growth of water hyacinth, so we can estimate that TDN/TDP was one of the inevitable factors of water hyacinth outbreak, and it can be used as one of the early warning indicators to predict the outbreak of water hyacinth. In practice, phosphorus can be considered the limiting factor for algal growth when the weight ratio of TDN and TDP is larger than 10 [26]. Therefore, the ratio of TDN/TDP in overlying waters in summer at Jintang and in summer and winter at Neijiang was much higher than 10 , indicating that phosphorus was one of the main limiting factors for the phytoplankton growth of plants in Tuohe River.

\section{Conclusions}

The profiles of the different forms of dissolved phosphorus and of diagenetic constituents in overlying and pore waters at the upstream site of Jintang and at the downstream site of Neijiang of the Tuohe River were used to understand the spatial and seasonal factors affecting the dynamics of phosphorus in this environment. Based on these profiles and TDN/TDP data, it was possible to determine that the main controlling factors of the different phosphorus species are the types of riverine sediments and the sedimentary redox conditions. In the Tuohe River, SRP was the main form of TDP in overlying waters. However, in the muddy sediments at Jintang, SRP was the main form of TDP in winter, while it was dominated by SUP in summer. In the sandy sediments of Neijiang, SUP was the main form of TDP in summer while 


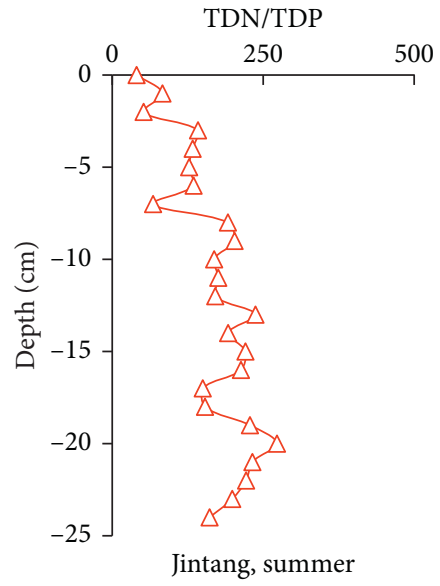

(a)

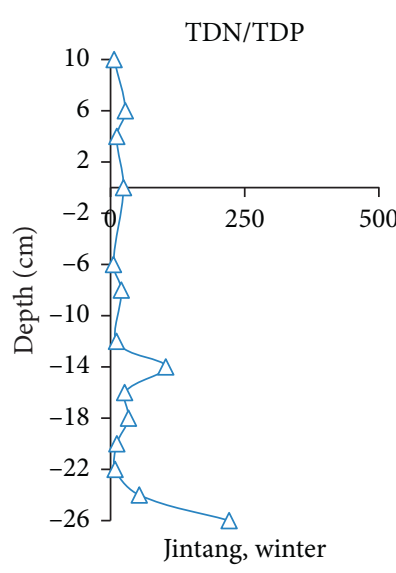

(b)

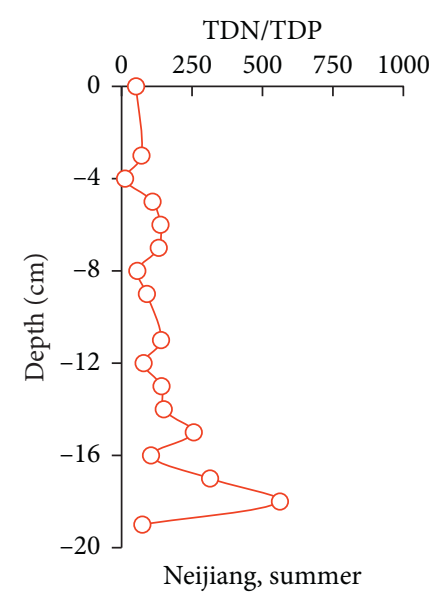

(c)

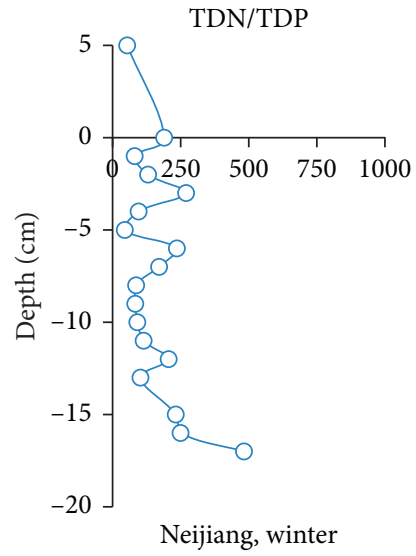

(d)

FIgURE 5: Vertical distributions of TDN/TDP in overlying waters at the two sampling sites.

SRP dominated in winter. The microbial degradation of organic matter, changes of oxidation state of the environment, $\mathrm{pH}, \mathrm{DO}$, temperature, river flow, and granular composition of the sediments all affected the vertical distribution and mobility of phosphorus species. The mean weight ratio of TDN/TDP in pore waters as well as in the overlying waters at both sampling sites was generally higher than 10 , so there was a potential for outbreaks of algal growth, but overall phosphorus has become the major factor limiting phytoplankton growth in the Tuohe River.

\section{Data Availability}

The data used to support the findings of this study are available from the corresponding author upon request.

\section{Conflicts of Interest}

The authors declare that there are no conflicts of interest regarding the publication of this paper.

\section{Acknowledgments}

This work was supported by the National Natural Science Foundation of China (grant nos. U1607129, U1607123, 21773170) and the Yangtze Scholars and Innovative Research Team of the Chinese University (grant no. IRT_17R81).

\section{References}

[1] W. Feng, F. Wu, Z. He et al., "Simulated bioavailability of phosphorus from aquatic macrophytes and phytoplankton by aqueous suspension and incubation with alkaline phosphatase," Science of the Total Environment, vol. 616-617, pp. 1431-1439, 2018.

[2] Y. Li, H. Z. Wang, X. M. Liang et al., "Total phytoplankton abundance is determined by phosphorus input: evidence from an 18-month fertilization experiment in four subtropical ponds," Canadian Journal of Fisheries and Aquatic Sciences, vol. 74, no. 9, pp. 1454-1461, 2017.
[3] W. Zhang, X. Jin, D. Liu, C. Lang, and B. Shan, “Temporal and spatial variation of nitrogen and phosphorus and eutrophication assessment for a typical arid river-Fuyang River in northern China," Journal of Environmental Sciences, vol. 55, pp. 41-48, 2017.

[4] Z. Ni, S. Wang, and Y. Wang, "Characteristics of bioavailable organic phosphorus in sediment and its contribution to lake eutrophication in China," Environmental Pollution, vol. 219, pp. 537-544, 2016.

[5] K. Meinikmann, M. Hupfer, and J. Lewandowski, "Phosphorus in groundwater discharge-a potential source for lake eutrophication," Journal of Hydrology, vol. 524, pp. 214-226, 2015.

[6] J. W. Lund, "Eutrophication," Nature, vol. 214, no. 5088, pp. 557-558, 1967.

[7] R. H. Li, J. Xu, X. F. Li et al., "Spatiotemporal variability in phosphorus species in the pearl river estuary: influence of the river discharge," Scientific Reports, vol. 7, no. 1, Article ID 13649, 2017.

[8] P. Lin, L. Guo, M. Chen, and Y. Cai, "Distribution, partitioning and mixing behavior of phosphorus species in the Jiulong River estuary," Marine Chemistry, vol. 157, pp. 93105, 2013.

[9] D. J. Evans and P. J. Johnes, "Physico-chemical controls on phosphorus cycling in two lowland streams. Part 1 -the water column," Science of the Total Environment, vol. 329, no. 1-3, pp. 145-163, 2004.

[10] H. Wang, J. Holden, K. Spera et al., "Phosphorus fluxes at the sediment-water interface in subtropical wetlands subjected to experimental warming: a microcosm study," Chemosphere, vol. 90, no. 6, pp. 1794-1804, 2013.

[11] X.-L. Huang and J.-Z. Zhang, "Spatial variation in sedimentwater exchange of phosphorus in Florida Bay: AMP as a model organic compound," Environmental Science \& Technology, vol. 44, no. 20, pp. 7790-7795, 2010.

[12] M. Du, Q. Liu, B. Luo et al., "Evaluation and analysis of present water environment quality of Minjiang \& Tuojiang river basins," Sichuan Environment, vol. 5, no. 35, pp. 20-25, 2016.

[13] T. Deng, Y. Wu, X. Yu, Y. Guo, Y.-W. Chen, and N. Belzile, "Seasonal variations of arsenic at the sediment-water interface of Poyang Lake, China," Applied Geochemistry, vol. 47, pp. 170-176, 2014. 
[14] M.-X. Liao and T.-L. Deng, "Arsenic species analysis in porewaters and sediments using hydride generation atomic fluorescence spectrometry," Journal of Environmental Sciences, vol. 18, no. 5, pp. 995-999, 2006.

[15] Q. Xu, X. Yu, Y. Guo, T. Deng, Y.-W. Chen, and N. Belzile, "Seasonal variations of phosphorus species in the Tuohe River, China. Part I. Sediments," Journal of Oceanology and Limnology, vol. 36, no. 6, pp. 1950-1961, 2018.

[16] S. W. Effler, A. R. Prestigiacomo, N. G. Hairston, M. T. Auer, A. Kuczynski, and S. C. Chapra, "Dissolved phosphorus concentrations in Cayuga Lake system and differences from two analytical protocols," Lake and Reservoir Management, vol. 32, no. 4, pp. 392-401, 2016.

[17] State Bureau of Quality and Technical Supervision, "Inorganic phosphorus: phosphorus molybdenum blue spectrophotometric," in The People's Republic of China National Standard GB 17378.4, State Bureau of Quality and Technical Supervision, Beijing, China, 2007.

[18] M. X. Liao, Environmental geochemistry on arsenic and antimony in sediment-water interface of Poyang Lake, Chengdu University of Technology, Chengdu, China, Ph.D. dissertation, 2005.

[19] State Environmental Protection Administration, Water and Wastewater Monitoring and Analysis Method, China Environmental Science Press, Beijing, China, 4th edition, 2002.

[20] C. S. Nautiyal, "An efficient microbiological growth medium for screening phosphate solubilizing microorganisms," FEMS Microbiology Letters, vol. 170, no. 1, pp. 265-270, 1999.

[21] N. Belzile, J. Pizarro, M. Filella, and J. Buffle, "Sediment diffusive fluxes of $\mathrm{Fe}, \mathrm{Mn}$, and $\mathrm{P}$ in a eutrophic lake: contribution of lateral versus bottom sediments," Aquatic Sciences, vol. 58, no. 4, pp. 327-354, 1996.

[22] K. B. Hu, Study on Physicochemical Characteristics and Phosphate Adsorption Behaviors of Sediments from the Yellow River, M.Sc. thesis, Beijing Forestry University, Beijing, China, 2011.

[23] J. Niu, Effects on the Growth and Tillering of Water Hyacinth at Different Nitrogen and Phosphorus Levels and the Basis for Scientific Salvage for Scientific Salvage, M.Sc. thesis, Soochow University, Suzhou, China, 2012.

[24] Y. Wu, Environmental Geochemistry of Nitrogen Species at the Sediment-Water Interface of Tuojiang River, M.Sc. thesis, Chengdu University of Technology, Chengdu, China, 2007.

[25] R. Zhang, Environmental Geochemistry of Nitrogen Species at the Sediment-Water Interface in Water of Tuojiang River, M.Sc. thesis, Chengdu University of Technology, Chengdu, China, 2008.

[26] F. Feng, Study on the Vertical Distribution of Sedimentary Microbial Biomass, Species of Carbon, Nitrogen, Phosphorus and Their Correlation, M.Sc. thesis, University of Chinese Academy of Sciences, Beijing, China, 2006. 

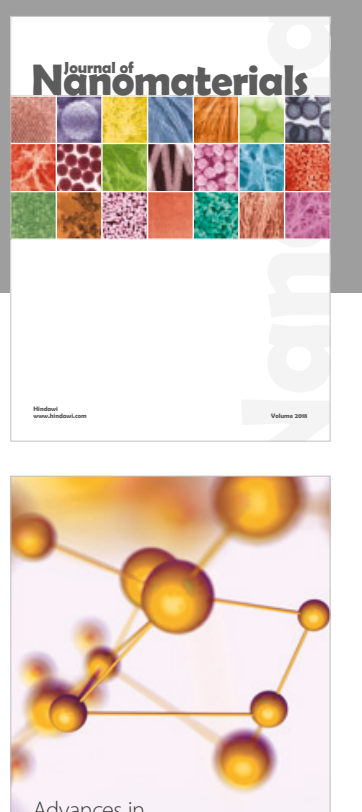

Physical Chemistry
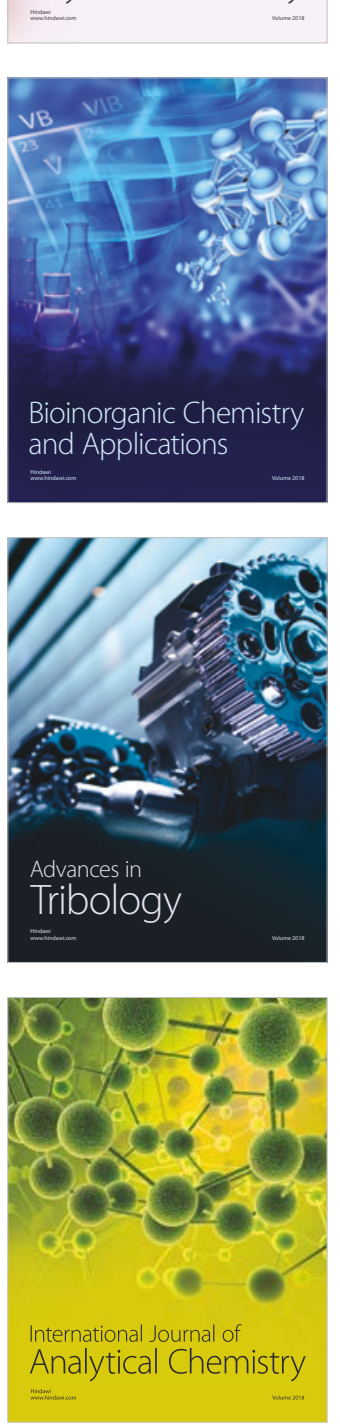

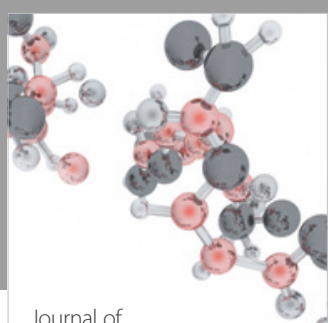

Analytical Methods

in Chemistry

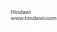

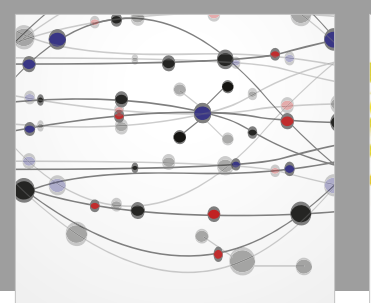

The Scientific World Journal

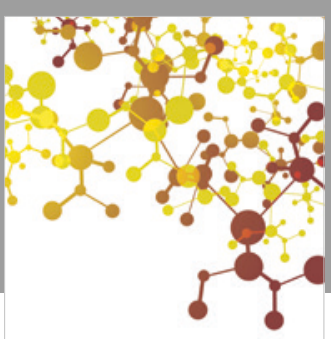

Journal of

Applied Chemistry
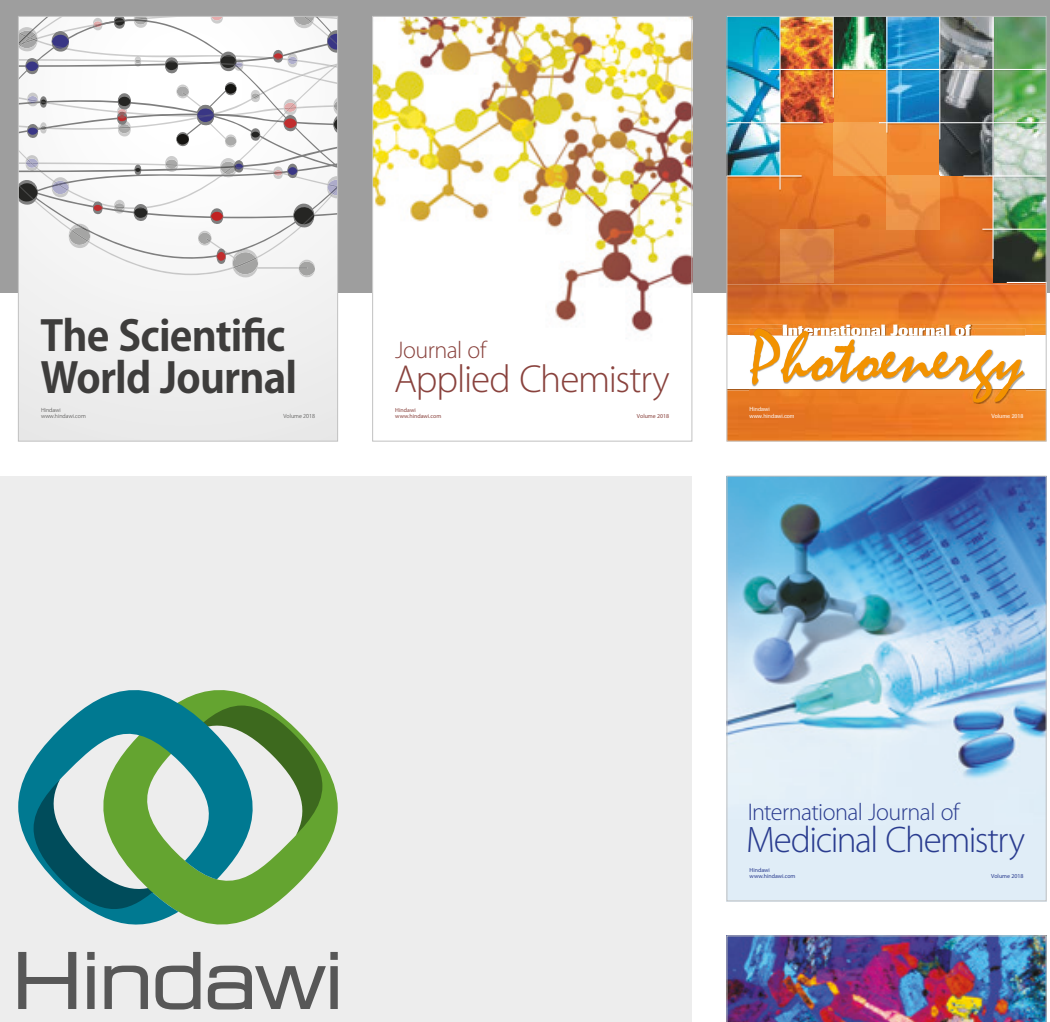

Submit your manuscripts at

www.hindawi.com
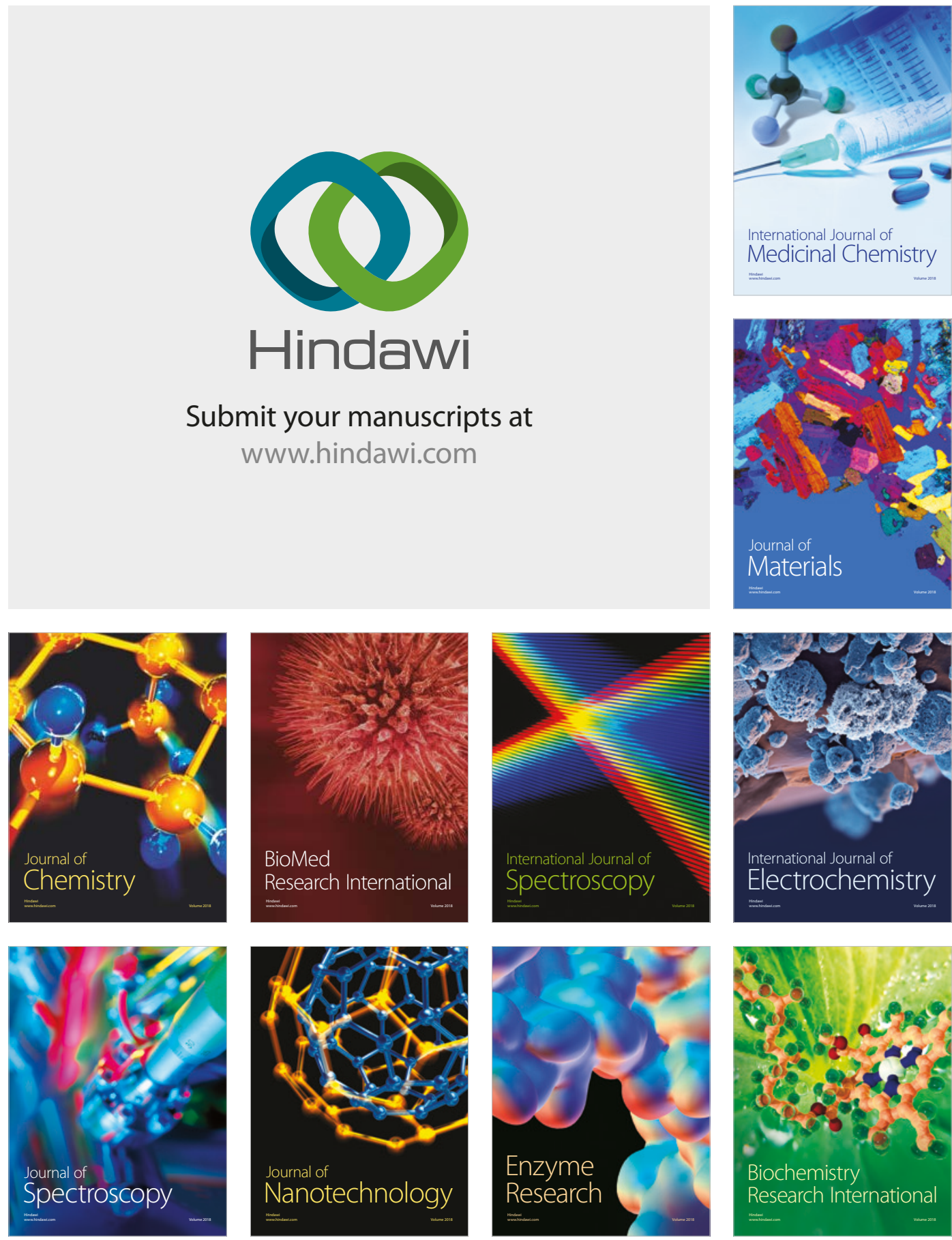
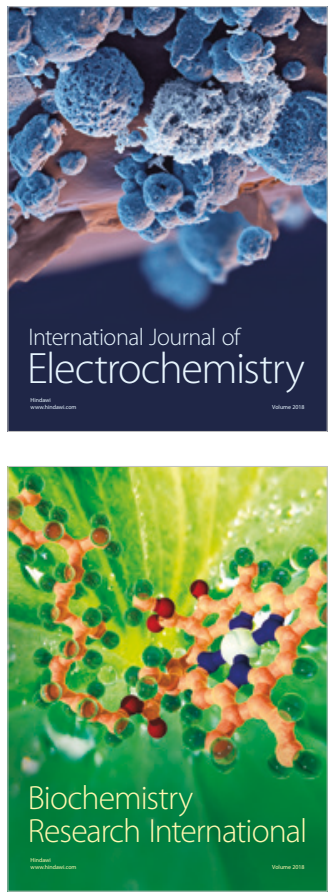